\title{
ADDITIONS TO THE ORIBATID MITE FAUNA OF MALAYSIA, WITH DESCRIPTION OF A NEW SPECIES OF THE GENUS LOHMANNIA (ACARI, ORIBATIDA, LOHMANNIIDAE)
}

\author{
Sergey G. Ermilov
}

Tyumen State University, Tyumen, Russia

E-mail: ermilovacari@yandex.ru

\begin{abstract}
The present study is based on oribatid mite material collected from leaf litter in the forest near Shari-la Island Resort, Coral Bay, Malaysia, in 2016. A list of identified taxa, including 15 species from 14 genera and 10 families, is presented; of these, one species is new for science: Lohmannia (Lohmannia) triangulata Ermilov sp. n. differs from L. (Lohmannia) hungarorum Mahunka, 1980 by the morphology of some prodorsal, notogastral and genital setae, and length of anterior exobothridial setae.
\end{abstract}

KEY WORDS: Oribatid mite, Lohmannia, systematics, morphology, Oriental region.

DOI: 10.21684/0132-8077-2016-24-2-159-165

\section{INTRODUCTION}

At present, the Malaysian oribatid mite fauna (Acari, Oribatida) is poorly known (Balogh and Mahunka 1974; Aoki, 1976; Mahunka 1988, 1995; Niedbała 2000). My investigation is based on material collected in 2016 from the forest near Sharila Island Resort, Coral Bay in Malaysia.

During taxonomic study, I discovered one new species belonging to the genus Lohmannia Michael, 1898. The main goal of the paper is to present a list of the identified taxa and to describe and illustrate a new species under the name Lohmannia (Lohmannia) triangulata Ermilov sp. n.

Lohmannia comprises two subgenera and 27 species, which are distributed in the Tropical and Subtropical regions (Subías 2004, online version 2016). The main generic traits were summarized by Balogh (1961) and Grandjean (1950).

\section{MATERIAL AND METHODS}

Material examined. Malaysia, $5^{\circ} 54^{\prime} 59.2^{\prime \prime} \mathrm{N}$, $102^{\circ} 42^{\prime} 59.9^{\prime \prime}$, Pulau Perhentian Kecil, Terengganu, leaf litter in forest near Shari-la Island Resort, Coral Bay, extracted by Berlese funnels, 12 June 2016 (R. V. Latyntsev).

Methods. Specimens were mounted in lactic acid on temporary cavity slides for measurement and illustration. The body length was measured in lateral view, from the tip of the rostrum to the posterior edge of the ventral plate. Notogastral width refers to the maximum width in dorsal aspect. Lengths of body setae were measured in lateral aspect. All body measurements are presented in micrometers $(\mu \mathrm{m})$. Formulas for leg setation are given in parentheses according to the sequence trochanter-femurgenu-tibia-tarsus (famulus included). Formulas for leg solenidia are given in square brackets according to the sequence genu-tibia-tarsus.
Morphological terminology used in this paper follows that of F. Grandjean: see Travé and Vachon (1975) for general references, Norton (1977) for leg setal nomenclature, and Norton and BehanPelletier (2009), for overview.

Drawings were made with a camera lucida using a Carl Zeiss transmission light microscope "Axioskop-2 Plus".

\section{LIST OF IDENTIFIED TAXA*}

\section{Lohmanniidae}

Javacarus kuehnelti Balogh, 1961. Distribution: Tropical region and Egypt.

Lohmannia (Lohmannia) triangulata sp. $\mathrm{n}$. Distribution: Malaysia.

\section{Astegistidae}

Cultroribula bicuspidata Mahunka, 1978. Distribution: Ethiopian, Neotropical and Oriental regions.

\section{Oppiidae}

Oppiella (Oppiella) nova (Oudemans, 1902). Distribution: Cosmopolitan.

\section{Suctobelbidae}

Suctobelbella variosetosa (Hammer, 1961). Distribution: Tropical region.

\section{Microzetidae}

Berlesezetes ornatissimus (Berlese, 1913). Distribution: Cosmopolitan.

\section{Oribatellidae}

Oribatella (Oribatella) malaya Balogh and Mahunka, 1974. Distribution: Oriental region.

*All specimens are deposited in the collection of the Tyumen State University Museum of Zoology, Tyumen, Russia. General known distribution see in Subías (2004, updated 2016). 


\section{S. G. Ermilov}

\section{Scheloribatidae}

Scheloribates (Scheloribates) praeincisus (Berlese 1910). Distribution: Tropical and southern Holarctic regions.

Scheloribates (Bischeloribates) mahunkai Subías, 2010. Distribution: Oriental region.

\section{Haplozetidae}

Haplozetes furtadoi Balogh and Mahunka, 1974. Distribution: Oriental region.

Trachyoribates (Rostrozetes) ovulum Berlese, 1908. Distribution: Tropical and Subtropical regions.

\section{Punctoribatidae}

Allozetes pusillus (Berlese, 1913). Distribution: Oriental region.

Lamellobates molecula (Berlese, 1916). Distribution: Tropical and Subtropical regions.

\section{Galumnidae}

Pergalumna (Pergalumna) hauseri Mahunka, 1995. Distribution: Oriental region.

Variogalumna singularis (Mahunka, 1995). Distribution: Oriental region.

In the course of taxonomic identification I found 15 species from 14 genera and 10 families. Of these, one species is new to science-Lohmannia (Lohmannia) triangulata sp. $\mathrm{n}$.

\section{DESCRIPTION}

\section{Lohmannia (Lohmannia) triangulata Ermilov sp. $\mathbf{n}$.}

Figs 1-7

Diagnosis. Body size: $879-898 \times 381-415$. Body surface densely tuberculate. Dorso-lateral parts of prodorsum with one pair of tubercles, lateral parts undulate, with four to five small teeth. Rostrum rounded. Rostral, lamellar, interlamellar and anterior exobothridial setae broadly phylliform, rounded distally, posterior exobothridial setae disk-like, all serrate. Bothridial setae pectinate, branches long. Notogastral setae phylliform, with serrate margins, $c_{3}$ dilated and truncate distally, $c_{1}, c_{2}, d_{1}, d_{2}, e_{1}, f_{1}$, and $h$ with rounded tips, other setae triangular, with point tips. One transverse band $\left(\mathrm{S}_{3}\right)$ visible dorsally, interrupted medially. Epimeral setae broadly phylliform, barbed. Two pairs of postero-lateral genital setae phylliform, other genital and also anal setae thickened. Adanal setae phylliform, triangular. Leg tibiae III with three setae ( $v$ ' present).

Description. Measurements. Large species. Body length: 898 (holotype), 879 (one paratype); notogaster width: 415 (holotype), 381 (one paratype). Sex not identified.
Integument (Figs. 1-5, 7). Body color brown. Body surface (including subcapitular mentum, genital, and adanal plates) and legs with dense microfoveolae forming mostly micropolygonal ornamentation, covered by tuberculate (diameter of tubercles up to 8) sculpture (except subcapitular mentum and anterior parts of legs). Macropolygonal pattern absent.

Prodorsum (Figs. 1, 3). Roughly triangular in dorsal view, occupying about $2 / 5$ of dorsal length, distinctly undulate laterally, with four to five small teeth, which are densely inserted in the median parts. Dorso-lateral sides with one pair of large tubercles $(t u b)$. Rostrum rounded. Rostral (ro, 123-135), lamellar (le, 57-65), interlamellar (in, 73-82) and anterior exobothridial (exa, 36-41) setae broadly phylliform, without distinct points distally, posterior exobothridial setae (exp, 57-61) disk-like, all setae distinctly and densely serrate. Bothridial setae (bs, 98-110) pectinate, with 11 to 12 branches on one sides, barbs on opposite sides absent. Postbothridial transverse band $\left(\mathrm{S}_{\mathrm{b}}\right)$ present.

Notogaster (Figs. 1-4). Anterior notogastral margin slightly concave medially. Sixteen pairs of notogastral setae phylliform, with serrate margins, $c_{3}(28-36)$ dilated and truncate distally, $c_{1}(57-65)$, $c_{2}(73-77), d_{1}, d_{2}, e_{1}, f_{1}$, and $h_{1}(57-65)$ with rounded tips, $d_{3}$ and $e_{2}(57-65)$ triangular, with short, point tips, $f_{2}(73-77), h_{2}, h_{3}$, and $p_{1}-p_{3}(90-94)$ triangular, with long tips. Lyrifissures $i a, i m$, and ip distinct, other lyrifissures not visible. One distinct transverse band $\left(\mathrm{S}_{3}\right)$ present dorsally, interrupted medially, other bands not visible between tubercles of surface. Two additional pairs (anterior and posterior) of ventral bands $\left(\mathrm{S}_{\mathrm{va}}, \mathrm{S}_{\mathrm{vp}}\right)$ located laterally to anogenital region.

Gnathosoma (Fig. 2). Similar to Lohmannia species (Grandjean 1950; Ermilov, in press.). Subcapitulum longer than wide (209-217×172 $-180)$, with one pair of lateral tubercles. Subcapitular setae $a(73-77)$ and $m_{1}$ (73-82) setiform, thickened, $a$ smooth, $m_{1}$ barbed, $m_{2}$ (45-53) and $h$ (36-41) phylliform, barbed. Adoral setae smooth, or ${ }_{1}$ (45) lobe-shaped, or 2 (53) thick, elongated, blunt-ended, or $_{3}$ (45) thickened, elongate triangular, pointed. Palps (98-102) with setation $0-1-0-3-10(+\omega)$. Distal three setae fused basally. Solenidia thickened, blunt-ended. Postpalpal setae (16) spiniform, slightly barbed. Chelicerae (233) with two setae, chb (61-65) setiform, barbed, cha (8) spiniform, smooth. Trägårdh's organ short, triangular. 
Additions to oribatid mite fauna of Malaysia

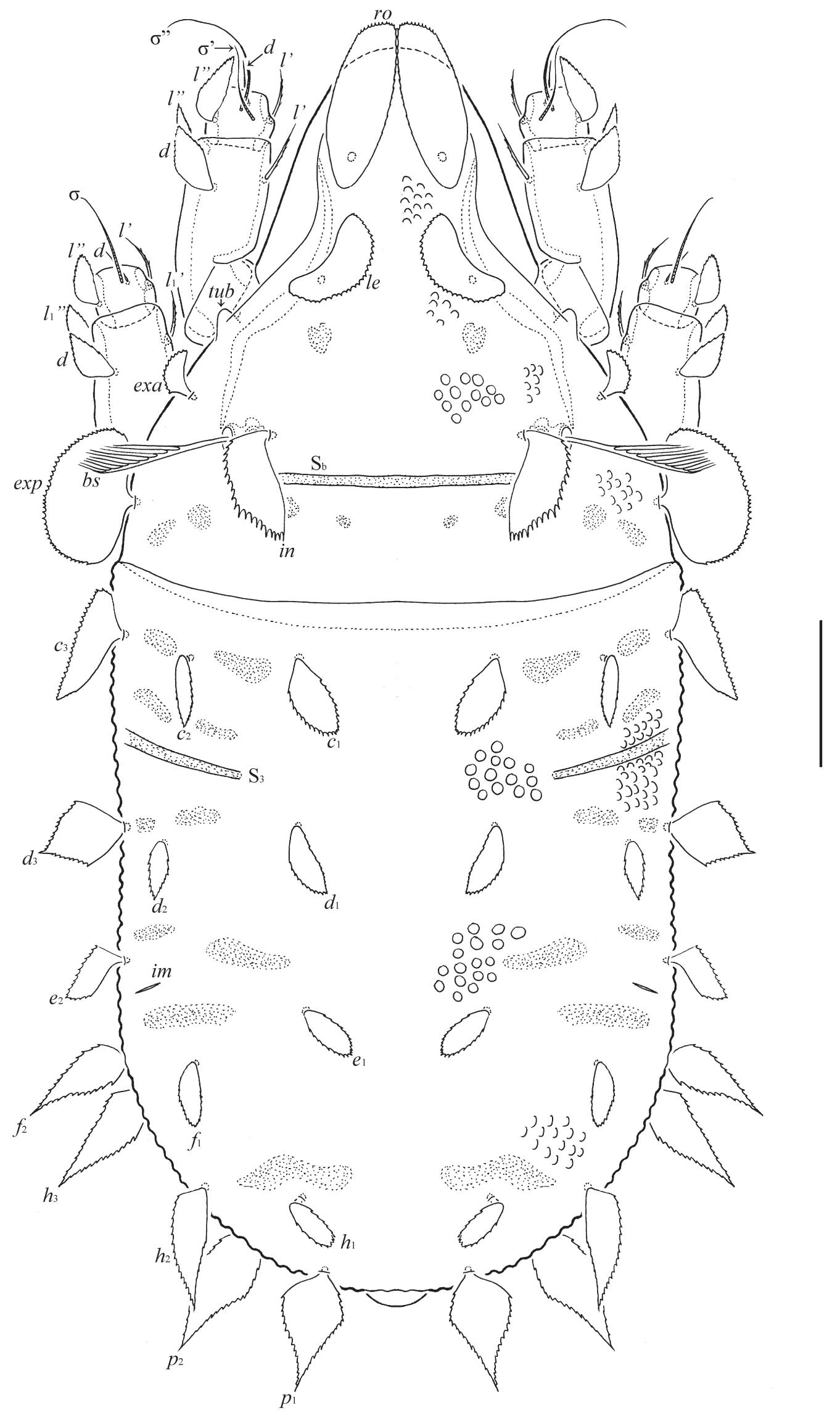

Fig. 1. Lohmannia (Lohmannia) triangulata Ermilov sp. n., adult: dorsal view (not shown: legs except basal parts I and II). Scale bar $100 \mu \mathrm{m}$. 


\section{S. G. Ermilov}

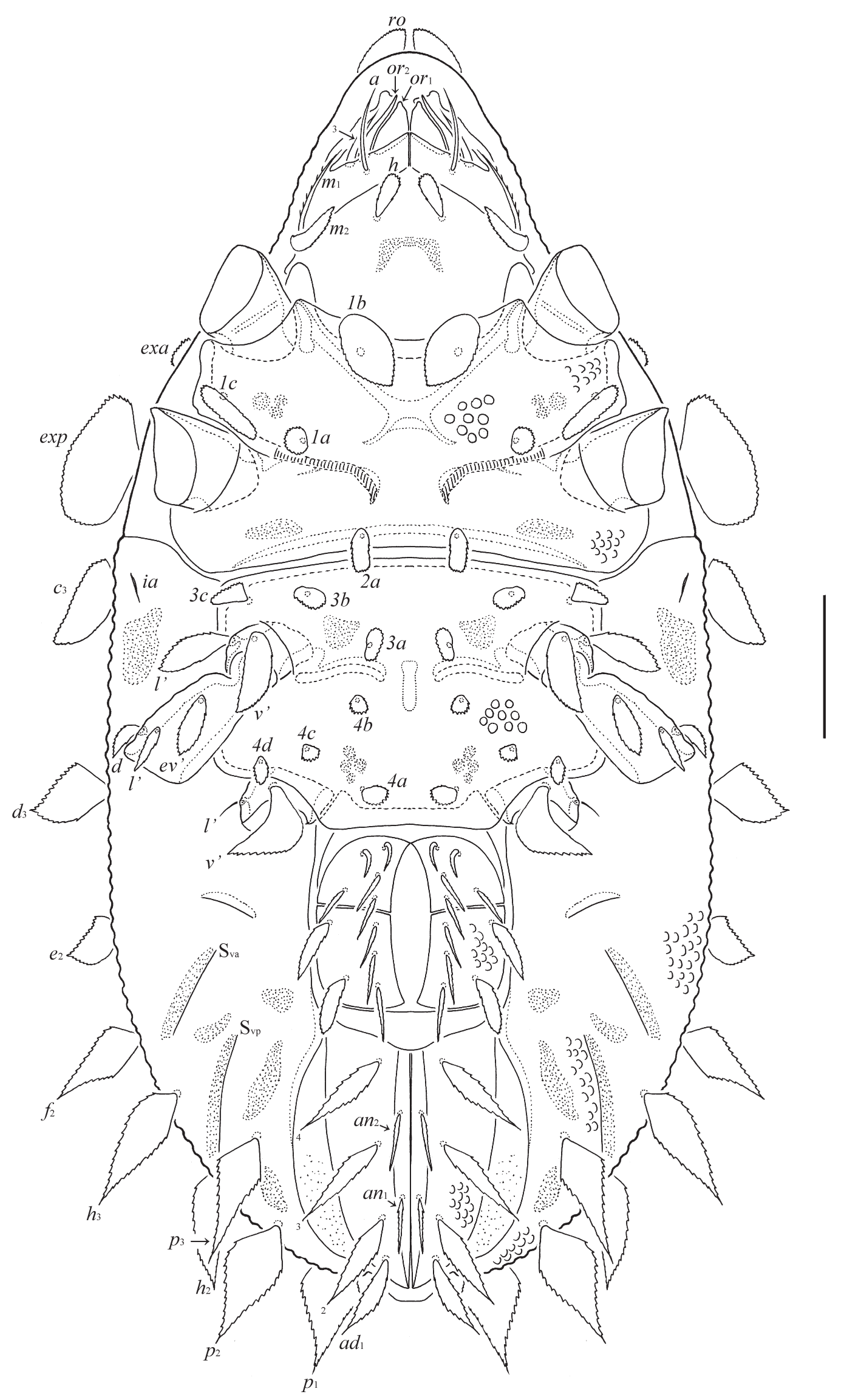

Fig. 2. Lohmannia (Lohmannia) triangulata Ermilov sp. n., adult: ventral view (not shown: legs except basal parts). Scale bar $100 \mu \mathrm{m}$. 


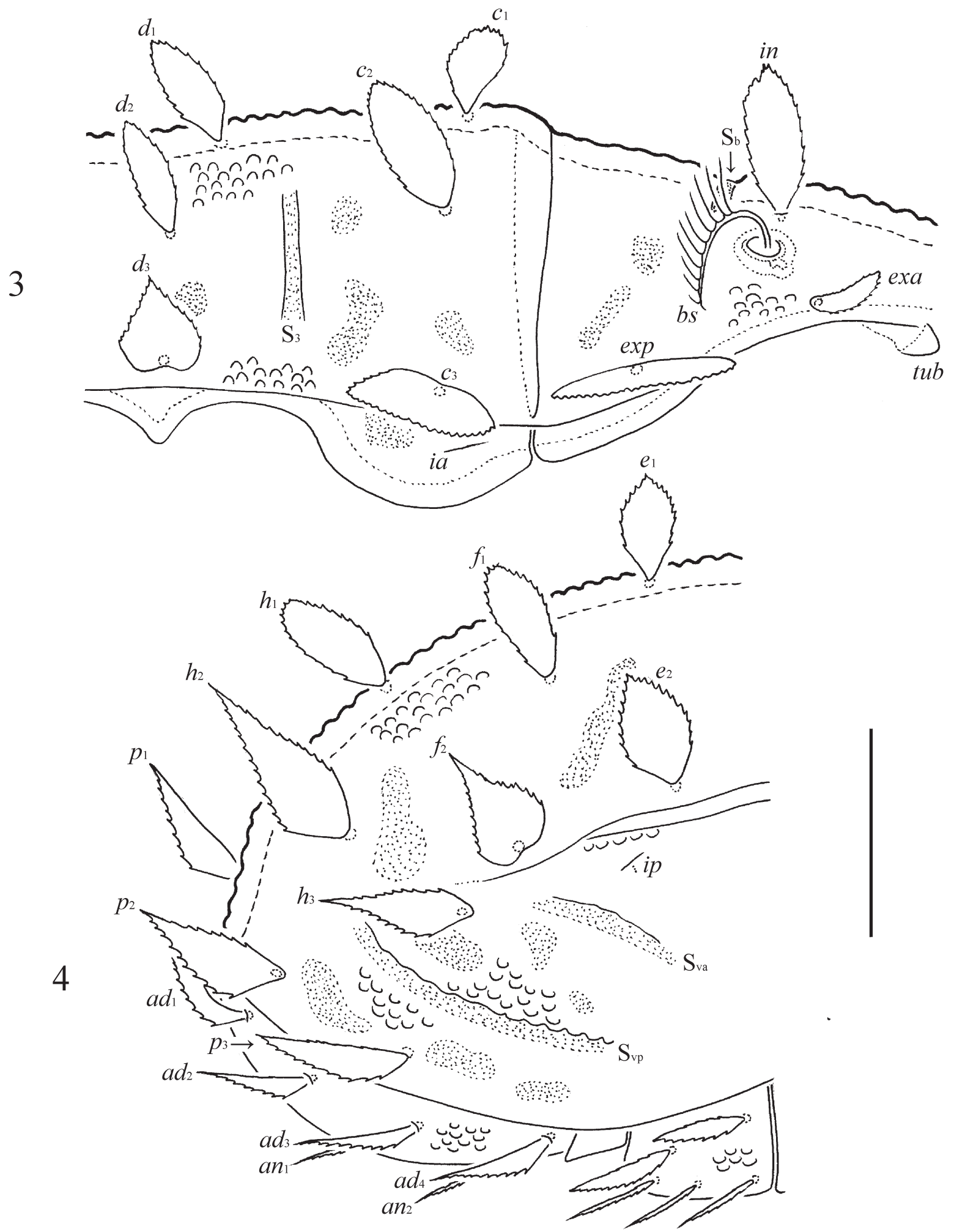

Figs. 3-4. Lohmannia (Lohmannia) triangulata Ermilov sp. n., adult: 3-posterior part of prodorsum and anterior part of notogaster, lateral view; 4 - posterior part of hysterosoma, lateral view. Scale bar $100 \mu \mathrm{m}$. 


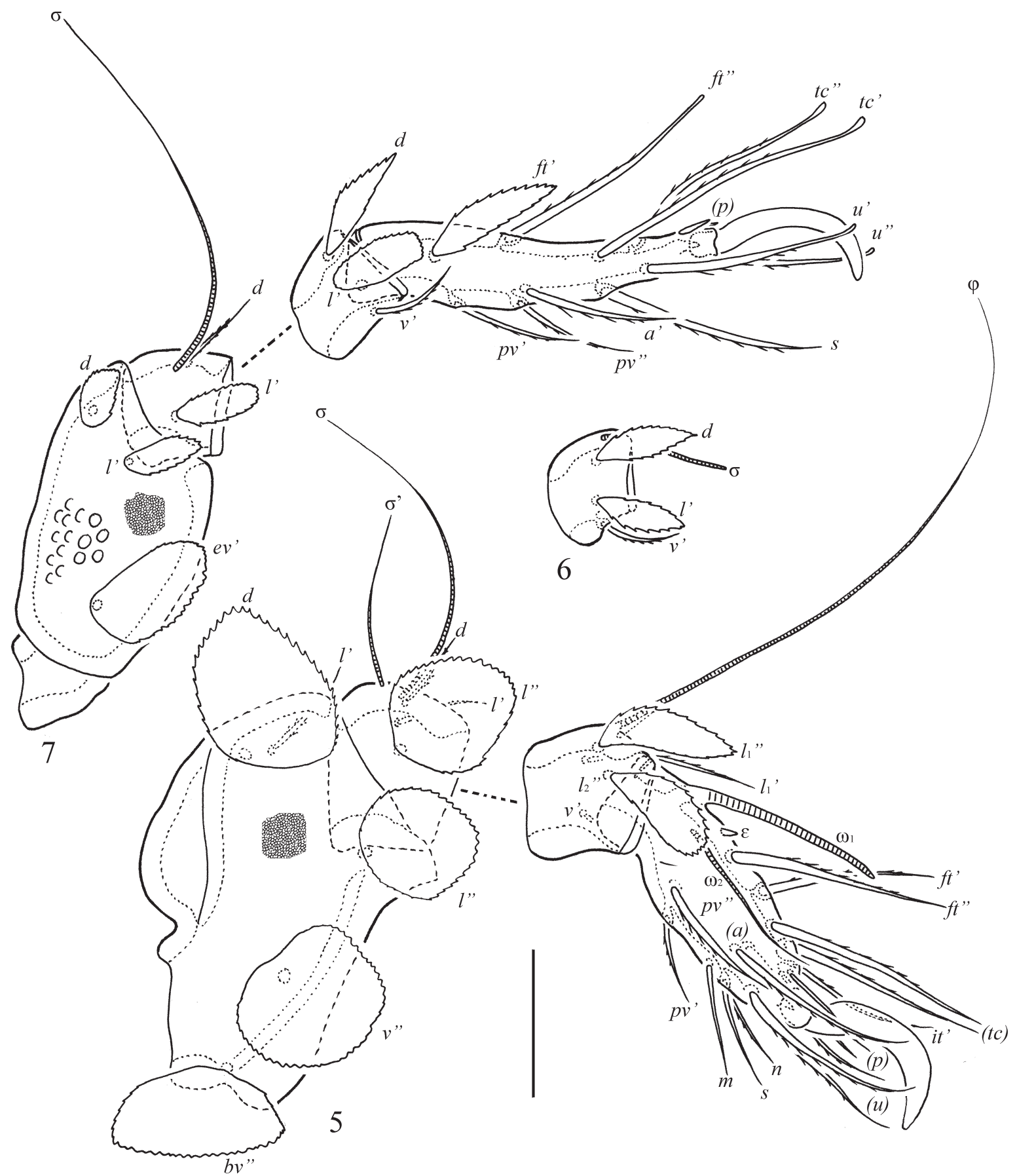

Figs. 5-7. Lohmannia (Lohmannia) triangulata Ermilov sp. n., adult: 5-leg I, except trochanter, right, antiaxial view; 6 - tibia of leg III, left, antiaxial view; 7-leg IV, left, antiaxial view. Scale bar $50 \mu \mathrm{m}$.

Epimeral and lateral podosomal regions (Fig. 2). Epimeral setal formula: 3-1-3-4. Setae broadly phylliform, barbed, $1 b$ and $1 c$ (45-53) larger than other setae (28-32).

Anogenital region (Figs. 2, 4). Medial setae (six pairs) and two pairs of antero-lateral setae (36-41) thickened, barbed, two pairs of postero-lateral setae (45-53) phylliform, barbed. Transverse genital furrows distinct. Two pairs of anal setae $\left(a n_{1}, a n_{2}\right.$, 36-41) thickened, barbed. Four pairs of adanal setae $\left(a d_{1}-a d_{4}, 73-77\right)$ phylliform, triangular, with long tips, serrate. Lyrifissures ian and iad not visible.

Legs (Figs. 1, 2, 5-7). Claw of each leg smooth. Formulas of leg setation and solenidia: leg I ( $0-5-3-$ 5-17) [2-1-2], leg II (0-6-3-5-13) [1-1-1], leg III (2-3-2-3-12) [1-1-0], leg IV (2-3-2-3-12) [1-0-0]; homology of setae and solenidia indicated in Table 1. Many setae (except tarsi) broadly phylliform. Solenidia $\omega_{1}$ on tarsi I, $\omega$ on tarsi II and $\varphi$ on tibiae III thickened, blunt-ended, other solenidia thin, setiform. 
Famuli $(\varepsilon)$ tubercle-like, inserted between solenidia $\omega_{1}$ and setae $f t$ ". Solenidia $\omega_{2}$ not coupled with setae.

Type deposition. The holotype is deposited in the collection of the Senckenberg Museum, Görlitz, Germany; one paratype is deposited in the collection of the Tyumen State University Museum of Zoology, Tyumen, Russia.

Etymology. The specific name "triangulata" refers to the morphology of some notogastral setae (triangular).

Remarks. Lohmannia (Lohmannia) triangulata Ermilov sp. $\mathrm{n}$. is most similar morphologically to L. (Lohmannia) hungarorum Mahunka, 1980 from the western Mediterranean (see Mahunka 1980) in having notogastral and adanal setae broadly phylliform, with pointed tips and disk-like posterior exobothridial setae, however differs by the morphology of some prodorsal (rostral and lamellar setae with rounded tips versus rostral and lamellar setae pointed in L. (Lohmannia) hungarorum), notogastral ( $c_{3}$ truncate distally, $c_{1}, c_{2}, d_{1}, d_{2}, e_{1}, f_{1}$, and $h_{1}$ with rounded tips versus $c_{1}, c_{2}, c_{3}, d_{1}, d_{2}, e_{1}, f_{1}$, and $h_{1}$ with pointed tips in L. (Lohmannia) hungarorum) and antero-lateral genital (thickened versus phylliform in L. (Lohmannia) hungarorum) setae and length of anterior exobothridial setae (shortest on prodorsum versus not shorter than lamellar and interlamellar setae in L. (Lohmannia) hungarorum).

\section{ACKNOWLEDGEMENTS}

I thank R. V. Latyntsev (Tyumen State University, Tyumen, Russia) for collecting oribatid mites from Malaysia. The present study was supported by the Russian Science Foundation, project No. 14-14-01134.

\section{REFERENCES}

Aoki, J. 1976. Oribatid mites from the IBP study area, Pasoh Forest Reserve, West Malaysia. Nature and Life in southeast Asia, 7: 39-59.
Balogh, J. 1961. An outline of the family Lohmanniidae Berlese, 1916 (Acari: Oribatei). Acta Zoologica Academiae Scientiarum Hungaricae, 7(1-2): 19-44.

Balogh, J. and Mahunka, S. 1974. Oribatid species (Acari) from Malaysian soils. Acta Zoologica Academiae Scientiarum Hungaricae, 20(3-4): 243-264.

Ermilov, S. G. A new species of Lohmannia (Lohmannia) (Acari, Oribatida, Lohmanniidae) from Vietnam, with supplementary description of L. (Lohmannia) turcmenica (Bulanova-Zachvatkina, 1960). Systematic and Applied Acarology, in press.

Grandjean, F. 1950. Etude sur les Lohmanniidae (Oribates, Acariens). Archives de Zoologie experimentale et generale, 87(2): 95-161.

Mahunka, S. 1988. New and interesting mites from the Geneva Museum LXI. Oribatids from Sabah (East Malaysia) III (Acari: Oribatida). Revue suisse de Zoologie, 95(3): 817-888.

Mahunka, S. 1995. Oribatids from Sabah, East Malaysia (Acari: Oribatida, Parakalummoidea, n. stat. and Galumnoidea). Tropical Zoology, 8: 269-308.

Niedbała, W. 2000. The ptyctimous mites of the Oriental and Australian regions and their centers of its origin (Acari: Oribatida). Genus, supplement: 1-493.

Norton, R. A. 1977. A review of F. Grandjean's system of leg chaetotaxy in the Oribatei (Acari) and its application to the family Damaeidae. In: D. L. Dindal (Ed.). Biology of Oribatid Mites. Syracuse: SUNY College of Environmental Science and Forestry: 33-61.

Norton, R. A. and Behan-Pelletier, V. M. 2009. Oribatida. In: G. W. Krantz and D. E. Walter (Eds.). A Manual of Acarology (TX). Lubbock, Texas University Press. Chapter 15, pp. 430-564.

Subías, L. S. 2004. Listado sistemático, sinonímico y biogeográfico de los ácaros oribátidos (Acariformes: Oribatida) del mundo. Graellsia, 60: 3-305. Online version updated in February 2016, 593 pp.

Travé, J. and Vachon, M. 1975. François Grandjean. 1882-1975 (Notice biographique et bibliographique). Acarologia, 17(1): 1-19.

Table 1.

Leg setation and solenidia of Lohmannia (Lohmannia) triangulata Ermilov sp. n.

\begin{tabular}{|l|l|l|l|l|l|}
\hline Leg & $\operatorname{Tr}$ & $\mathrm{Fe}$ & $\mathrm{Ge}$ & $\mathrm{Ti}$ & $\mathrm{Ta}$ \\
\hline $\mathrm{I}$ & - & $d,(l), b v^{\prime}, v^{\prime}$, & $(l), \underline{d \sigma^{\prime}}, \sigma^{\prime}$ & $\left(l_{1}\right), l_{2}^{\prime}, v^{\prime}, \underline{d \varphi}$ & $(f t), i t^{\prime},(t c),(p),(u),(a), s, m, n,(p v), \varepsilon, \omega_{1}, \omega_{2}$ \\
\hline II & - & $d,(l), l_{2},, b v^{\prime}, v^{\prime}$ & $(l), \underline{d \sigma}$ & $\left(l_{1}\right), l_{2},, v^{\prime}, \underline{d \varphi}$ & $(f t),(t c),(p),(u),(a), s,(p v), \omega$ \\
\hline III & $l^{\prime}, v^{\prime}$ & $d, l^{\prime}, e v^{\prime}$ & $l^{\prime}, d, \sigma$ & $d, l^{\prime}, v^{\prime}, \varphi$ & $(f t),(t c),(p),(u), a^{\prime}, s,(p v)$ \\
\hline IV & $l^{\prime}, v^{\prime}$ & $d, l^{\prime}, e v^{\prime}$ & $l^{\prime}, d, \sigma$ & $d, l^{\prime}, v^{\prime}$ & $(f t),(t c),(p),(u), a^{\prime}, s,(p v)$ \\
\hline
\end{tabular}

Note: Roman letters refer to normal setae, Greek letters to solenidia (except $\varepsilon=$ famulus), $\underline{d \sigma}$ and $\underline{d \varphi}$ - seta and solenidion coupled. Single prime (') marks setae on anterior and double prime (") setae on posterior side of the given leg segment. Parentheses refer to a pair of setae. $\mathrm{Tr}$ - trochanter, $\mathrm{Fe}-\mathrm{femur}, \mathrm{Ge}-\mathrm{genu}, \mathrm{Ti}-\mathrm{Tibia}, \mathrm{Ta}-\mathrm{tarsus}$. 



\title{
REDESCRIPTION OF PANTELOZETES CROSBYI (BERLESE, 1908) (ACARI, ORIBATIDA, THYRISOMIDAE)
}

\author{
Sergey G. Ermilov
}

Tyumen State University, Tyumen, Russia

E-mail: ermilovacari@yandex.ru

ABSTRACT: The redescription of Pantelozetes crosbyi (Berlese 1908) (Oribatida, Thyrisomidae) is presented, based on material from Missouri, USA. The main morphological traits for this species are summarized.

KEY WORDS: Oribatid mite, Pantelozetes, systematics, morphology, redescription, USA.

DOI: 10.21684/0132-8077-2016-24-2-167-173

\section{INTRODUCTION}

The oribatid mite Pantelozetes crosbyi (Berlese, 1908) (Acari, Oribatida, Thyrisomidae) was described as Oribella crosbyi from USA (Missouri) and Italia (Berlese 1908). At present, this species is recorded in the Holarctic region (Marshal et al. 1987; Subías 2004, online version 2016). Wen (1992) described the subspecies-Pantelozetes crosbyi maoershanensis (as representative of Oribella) from northern China.

The original description (Berlese 1908, see also Berlese 1910) and supplementary description (Fujikawa 1979) of $P$. crosbyi is incomplete, brief and poorly illustrated (lacking information about some morphological structures and their measures, leg setation and solenidia, morphology of gnathoso$\mathrm{ma})$. The main goal of the paper is to present redescription of this species, on the basis of topotypes from USA, and to summarize the main morphological traits, which will help with identification of P. crosbyi in the future.

\section{MATERIAL AND METHODS}

Material. Four topotypes (two females and two males) of Pantelozetes crosbyi (Berlese 1908) were received from Prof. Dr. Roy A. Norton (personal collection). Material examined: USA, Missouri, Boone County, near Hinkson Creek, south of the University of Missouri campus, moss on the base of tree, 24 May 1985 (J. Kethley and R. A. Norton).

Methods. Specimens were mounted in lactic acid on temporary cavity slides for measurement and illustration. The body length was measured in lateral view, from the tip of the rostrum to the posterior edge of the ventral plate. Notogastral width refers to the maximum width in dorsal aspect. Lengths of body setae were measured in lateral aspect. All body measurements are presented in micrometers. Formulas for leg setation are given in parentheses according to the sequence trochanterfemur-genu-tibia-tarsus (famulus included). Formulas for leg solenidia are given in square brackets according to the sequence genu-tibia-tarsus.

Morphological terminology used in this paper follows that of F. Grandjean: see Travé and Vachon (1975) for references, Norton (1977) for leg setal nomenclature, and Norton and Behan-Pelletier (2009) for overview.

Drawings were made with a camera lucida using a Carl Zeiss transmission light microscope “Axioskop-2 Plus". Images were obtained with an AxioCam ICc3 camera using a Carl Zeiss transmission light microscope "Axio Lab.A1".

\section{SYSTEMATICS}

\section{Pantelozetes crosbyi (Berlese, 1908)}

Figs 1-19

Description. Measurements. Body length: 381-398 (four topotypes: two females and two males); notogaster width: 199-224 (four topotypes). No clear difference between females and males.

Integument (Figs. 3, 15). Body color light brown. Body surface, subcapitular mentum and genae, genital and anal plates punctate, visible only under high magnification $(\times 1000)$ in dissected specimens. Lateral sides of prodorsum (between acetabula and bothridia) tuberculate (diameter of tubercles up to 4).

Prodorsum (Figs. 1, 3, 13-15). Rostrum rounded, teeth absent. Costulae (cos) shorter than half of prodorsum length. Rostral (ro, 36-45), lamellar (le, 36-45) and exobothridial (ex, 24-28) setae thin, setiform; ro distinctly barbed, inserted dorsally, le almost smooth, sometimes with sparse, indistinct barbs, inserted on the costular ends, ex slightly barbed, located on small tubercles. Interlamellar setae (in, 36-45) thickened, blunted, erect, 